\title{
Induction of Apoptosis in neoplastic cells by depletion of vitamin $B_{12}$
}

\author{
P. Roy Walker ${ }^{1,4}$, Brandon Smith ${ }^{1}$, Christine Carson ${ }^{1}$, Julie \\ LeBlanc ${ }^{1}$, Marianna Sikorska ${ }^{1}$, Clive S. Woodhouse ${ }^{2}$ and A. \\ Charles Morgan ${ }^{2,3}$ \\ ${ }^{1}$ Apoptosis Research Group, Institute for Biological Sciences, National \\ Research Council of Canada, Ottawa, Canada \\ 2 Receptagen Corporation, 190, West Dayton, Edmonds, Washington, USA \\ 98020 \\ 3 Dept. of Radiation Oncology, University of Washington, Seattle, WA, USA \\ ${ }^{4}$ corresponding author: Apoptosis Research Group, Institute for Biological \\ Sciences, National Research Council, Bldg. M54, Montreal Rd., Ottawa, Ont. \\ CANADA K1A 0R6. tel: (613) 993-2892; fax: (613) 990-7963; email: \\ roy.walker@nrc.ca
}

Received 24.8.96; revised 7.10.96; accepted 8.10.96 Edited by A. Finazzi-Agró

\begin{abstract}
Methionine synthase, a critical enzyme in deoxyribonucleotide biosynthesis for DNA replication, requires vitamin $B_{12}$ as a cofactor. We have tested the hypothesis that depletion of cells of vitamin $B_{12}$ would block growth of neoplastic cells and divert them into apoptosis and could form the basis of a new therapeutic strategy for cancer treatment. Using nitrous oxide to inactivate vitamin $B_{12}$ we show that, in a variety of cell lines in vitro, methionine synthase is rapidly inhibited, the cells cease proliferation and undergo apoptosis. The kinetics of cell death, once started, are similar to those observed following methotrexate treatment or serum withdrawal. This is the first observation of apoptosis being induced following depletion of an essential metabolite as opposed to the more conventional strategy of adding a toxic drug to damage cells thereby triggering apoptosis. Moreover, vitamin $\mathrm{B}_{12}$ depletion has no effect on the nonproliferating cell population.
\end{abstract}

Keywords: transcobalamin, growth blocker, apoptosis, methionine synthase, K562

Abbreviations: dTTP, deoxythymidine triphosphate; MeTHF, methyltetrahydrofolic acid; MS, methionine synthase; MTX, methotrexate; $\mathrm{N}_{2} \mathrm{O}$, nitrous oxide gas; TCII, transcobalamin II

\section{Introduction}

Vitamin $B_{12}$ is an essential cofactor for two enzymes. Methionine synthase (MS) which catalyses the conversion of homocysteine into methionine using methyl tetrahydrofolic acid (MeTHF) as a carbon donor and methylmalonylCoA mutase which catalyses the conversion of methylmalonylCoA to succinylCoA. Methionine synthase uses methyl-cobalamin as cofactor whereas methylmalonylCoA mutase uses adenosyl-cobalamin. Methionine synthase not only provides methionine for protein synthesis, but also serves as the entry point of dietary folates into the folate cycle. Folates from the diet are converted into MeTHF in the digestive tract during absorption and then circulated as such to peripheral tissues. Since the folate cycle provides reducing equivalents and a methyl group for the conversion of dUMP to dTMP during nucleotide biosynthesis MS activity is also essential for DNA replication. The availability of vitamin $B_{12}$ is, therefore, also crucial for nucleotide synthesis and DNA replication. As with folates, vitamin $B_{12}$ is also obtained from the diet and transported in the blood by its specific carrier, transcobalamin II (TCII). Cellular uptake of vitamin $\mathrm{B}_{12}$ requires the expression of a specific vitamin $B_{12}-\mathrm{TCll}$ receptor on the surface of cells. Receptor expression is generally coupled to DNA replication (Hall, 1984; Amagaski et al, 1990). Peripheral blood lymphocytes, for example, only express a high affinity receptor for cobalamin during the S-phase of the cell cycle. The receptor responsible is rapidly down-regulated in other phases of the cell cycle and when cells undergo differentiation (Lindemans et al, 1989).

The folate cycle has long been considered a good target for therapeutic strategies and a number of antifolate analogues, most notably methotrexate (MTX), have proved to be useful. Methotrexate inhibits dihydrofolate reductase, preventing the regeneration of THF, and bringing the folate cycle to a halt. The resulting lack of dTTP causes nucleotide imbalance which leads to misincorporation of nucleotides into DNA and eventually leads to the death of the cell by apoptosis (James et al, 1994). Deficiency in dietary folate also leads to apoptosis in primary cultures of proerythroblasts isolated and subsequently incubated in folate-deficient media (Koury and Horne, 1994). Methotrexate, however, is not just specific for proliferating cells and there is a toxic accumulation of the drug in non-proliferating cells such as liver.

Depletion of a cell of vitamin $B_{12}$, leading to inibition of MS, would be expected to have a similar effect as MTX. Indeed, experiments carried out by Lassen and Kristen (1959), Eastwood et al (1963) and lkeda et al (1989), using nitrous oxide gas to cause a whole body $B_{12}$ depletion in patients with leukemias, established that white blood cell counts could be effectively reduced to the point of disease remission. Similar results have been obtained in a mouse ascites tumour model (Parbrook, 1967) and in experimental rat leukemia models (Ermens et al, 1989; Abels et al, 1990). Nitrous oxide oxidizes Coll to Colll rendering cobalamin inactive (Banks et al, 1968) leading to inhibition of MS activity (Deacon et al, 1980; Kondo et al, 1981), but not methylmalonylCoa mutase activity (Kondo et al, 1981; Chanarin et al, 1985) at least during short-term exposures. Therefore, the growth inhibitory effects of nitrous oxide are more likely to act via inhibition of MS than methylmalonylCoA mutase. Although feasibility of this approach has 
been demonstrated in vivo, consistent results have not been seen in vitro using established tumour cell lines and this has hampered progress in this area. Consequently, despite the potential of $\mathrm{B}_{12}$ depletion as a therapeutic strategy it has been much less studied than folate depletion.

Since, it is now apparent that apoptosis, as opposed to necrosis, represents the major mechanism by which cells die within the body there is tremendous interest in exploiting the therapeutic potential of apoptosis in cancer therapy (Kerr et al, 1994; Hickman et al, 1994; Fisher, 1994). Indeed, most current therapeutically useful drugs and metabolic inhibitors have been found to induce apoptosis albeit indirectly (Walker et al, 1991; Hickman et al, 1994). The true potential of exploiting apoptosis will come from the development of novel strategies that are not directly toxic to cells, but can still activate apoptosis. Cells appear to have sensors that monitor damage or metabolic imbalance and, above a certain threshold, apoptosis is activated and the cells are eliminated. The objective, therefore, is to activate such sensors using protocols that avoid the undesirable side effects encountered in the use of the current generation of nonspecific or broad specificity inhibitors. This may be more readily achievable by specifically removing an essential cellular component rather than trying to inhibit a process or cause intracellular damage. In this study, we have investigated the feasibility of this approach by depleting a variety of neoplastic cells of vitamin $B_{12}$ and show that, under appropriate conditions, it is as effective a trigger of apoptosis as MTX treatment. These results suggest that a new generation of growthblocker drugs, aimed at reproducibly inducing apoptosis in cancer cells through targeting of vitamin $\mathrm{B}_{12}$ metabolism, may be devised.

\section{Results}

\section{Effects of nitrous oxide on cell growth}

Mouse L1210 cells were plated at $0.2 \times 10^{6} \mathrm{cells} / \mathrm{ml}$ in complete RPMI or in media depleted in either $B_{12}\left(-B_{12}\right)$ or both folate and $\mathrm{B}_{12}$ (-folate/ $\left.\mathrm{B}_{12}\right)$ and incubated in either air$\mathrm{CO}_{2}$ (cells in complete medium) or the $\mathrm{N}_{2} \mathrm{O}$ gas mixture (cells in $\mathrm{B}_{12}$ or folate/ $\mathrm{B}_{12}$-depleted media). Some cells were also plated in serum-free complete medium. Growth was followed over a 15 day period with the cells being split back to their starting cell density every 3-4 days (Figure 1). Under these conditions, the cells plated in complete medium and incubated in air- $\mathrm{CO}_{2}$ completed approximately three cell divisions every 3-4 days while producing negligible amount of dead cells (Figure 1A). In contrast, cells incubated in serum-free RPMI underwent one cell cycle during the first 3 days and then rapidly lost viability by day 6 . Attempts to adapt L1210 cells to the serum-free medium, supplemented solely by bovine serum albumin as described by Kondo et al (1989) were unsuccessful. The growth of cells incubated in RPMI $\mathrm{B}_{12}$ (in the presence of $\mathrm{N}_{2} \mathrm{O}$ ) was not significantly different from those of the controls in normal RPMI until after day 8 when growth became slightly, but consistently reduced (Figure 1A). However, cells plated in media depleted in both folate and $\mathrm{B}_{12}$ grew poorly after day 3 (Figure $1 \mathrm{~B}$ ) and the culture rapidly lost viability after 10 days in either of these media (Figure 1C).

Similar results were obtained for two other cell lines, human K562 (Figure 2A and B) and mouse BW5147.3 cells (Figure $2 \mathrm{C}$ and $\mathrm{D}$ ). In both cases, the cells quickly lost viability in serum-free media which we have previously shown to be via apoptosis (Walker et al, 1995). After completing two cell cycles, the cells were unable to proliferate further in medium depleted of both folate and vitamin $\mathrm{B}_{12}$. After 5 or 6 days in depleted media (in the presence of the $\mathrm{N}_{2} \mathrm{O}$ gas mixture) both cultures lost viability. Over the 8 days of the experiment, growth of
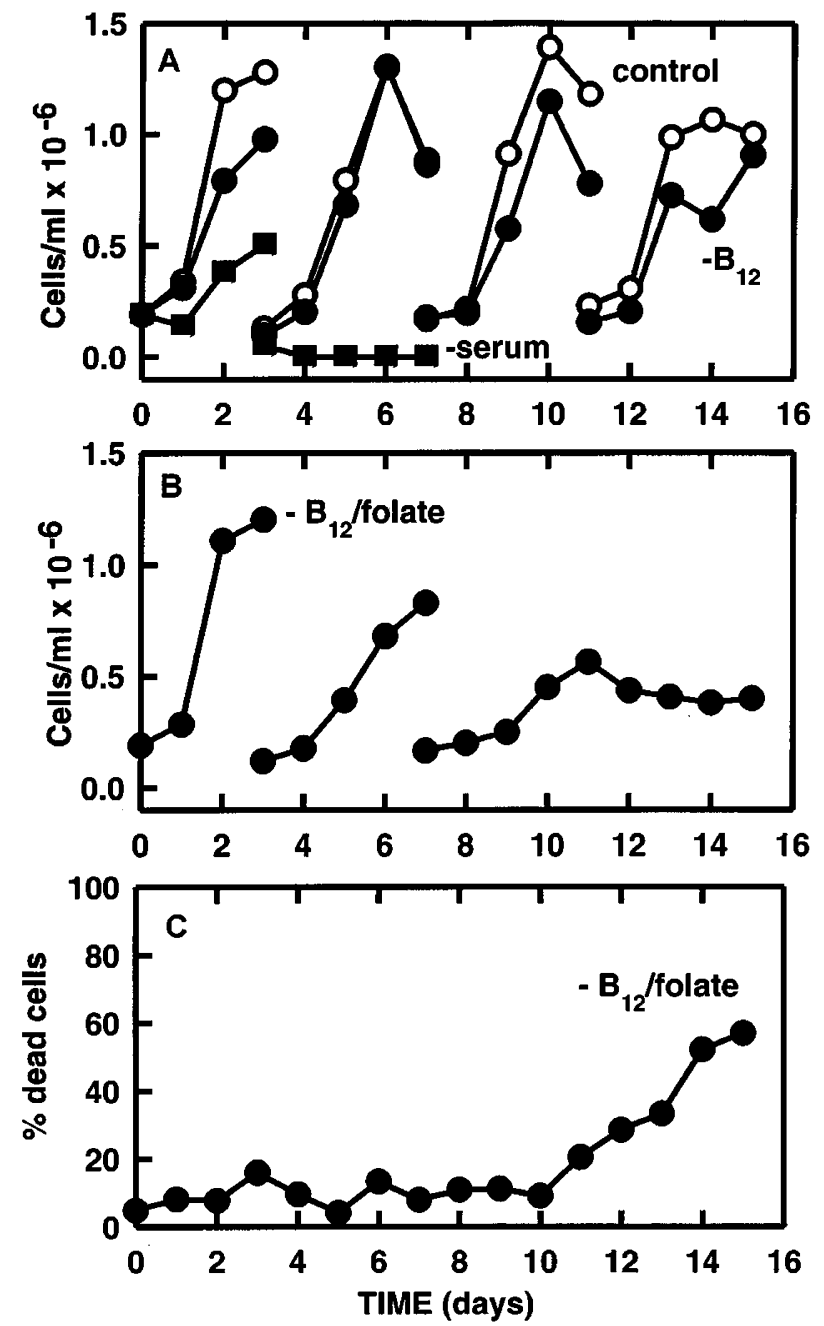

Figure 1 Growth of L1210 cells in normal or serum-free media (-serum), or media depleted of either only vitamin $B_{12}\left(-B_{12}\right)$, or depleted of both vitamin $B_{12}$ and folate $\left(-B_{12} /\right.$ folate). In $A$, cells were plated at $0.2 \times 10^{6} \mathrm{cells} / \mathrm{ml}$ in normal RPMI $+10 \%$ FBS (open circles, control), in the same medium without serum (closed squares, -serum) or in $\mathrm{B}_{12}$-depleted medium $+10 \%$ FBS in the presence of $\mathrm{N}_{2} \mathrm{O}$ (closed circles, $-\mathrm{B}_{12}$ ). Cells were split back to the starting density as indicated. In $B$ and $C$, cells were plated as above in medium without folic acid and $B_{12}\left(-B_{12} /\right.$ folate $)$ and incubated in the presence of $\mathrm{N}_{2} \mathrm{O}$. $A$ and $B$ show cell growth, $\mathrm{C}$ shows the percentage of dead cells for the experiment in B. 
A
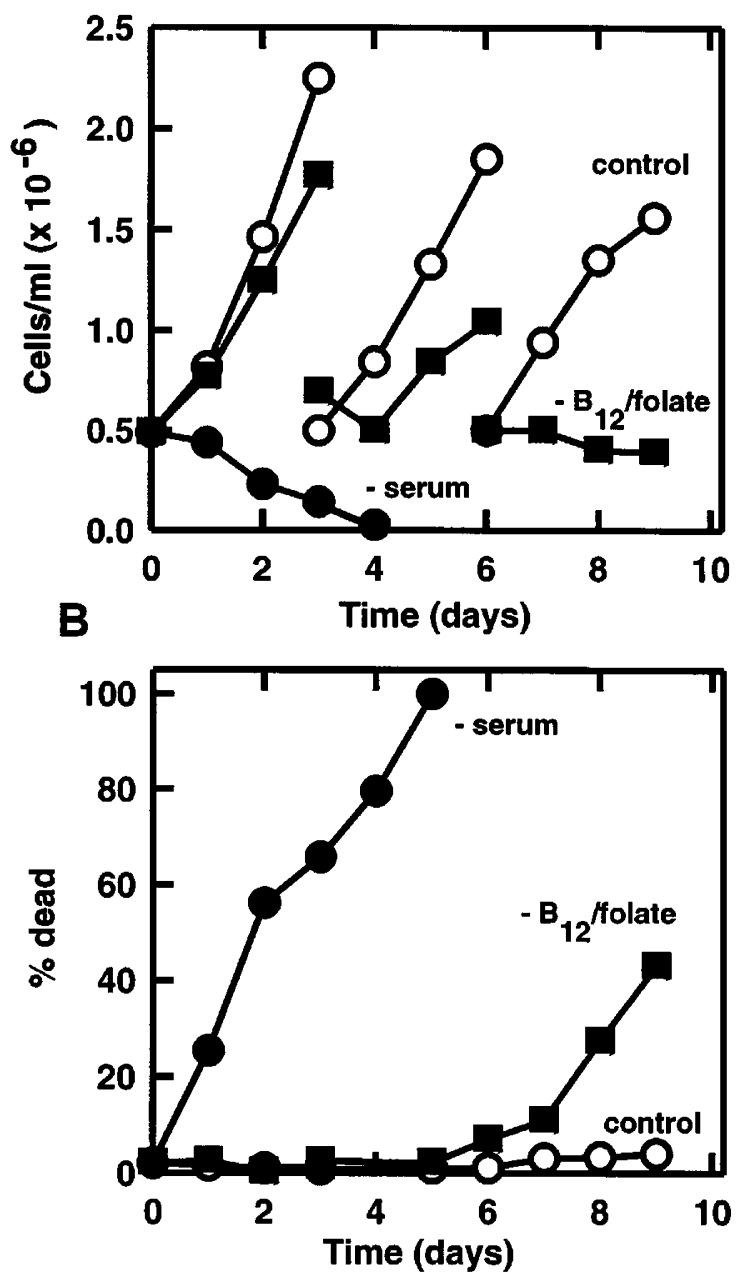

C
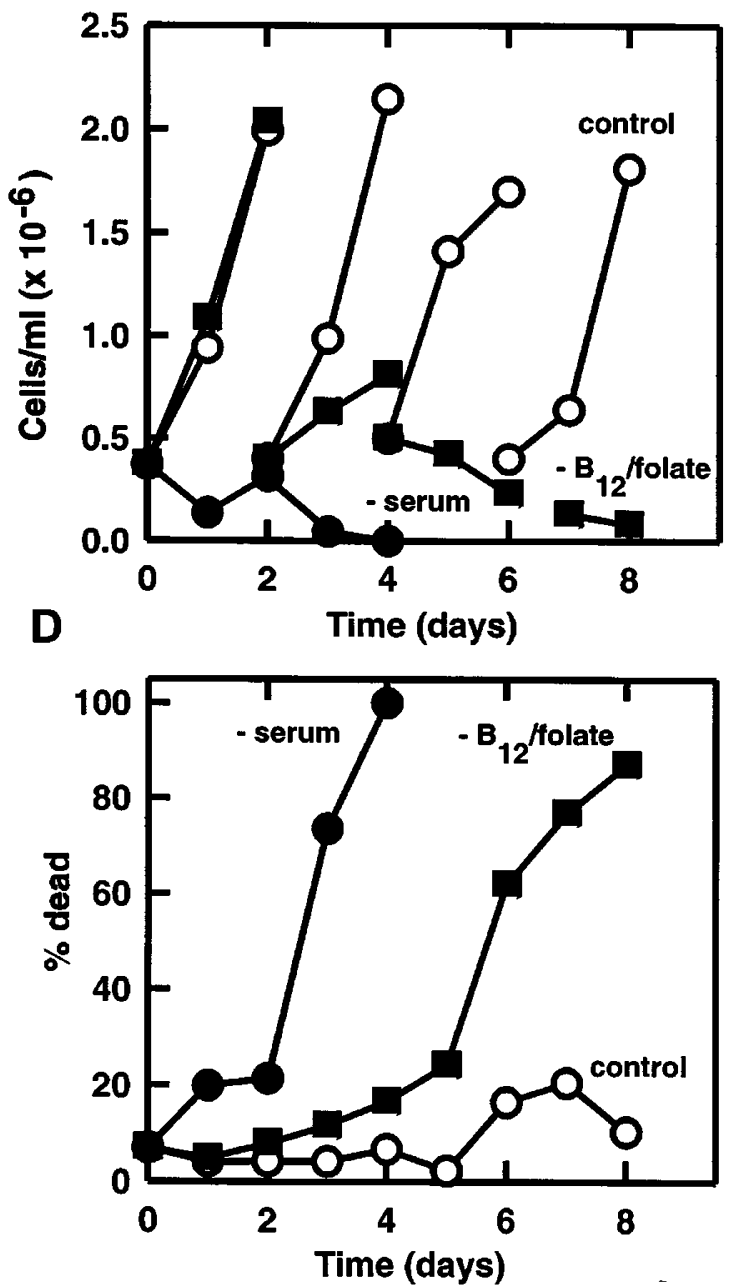

Figure 2 Growth of K562 (A,B) and BW5147.3 (C,D) cells in normal medium (with air- $\mathrm{CO}_{2}$ ) or medium depleted in both vitamin $\mathrm{B}_{12}$ and folate $\left(-\mathrm{B}_{12} /\right.$ folate $+\mathrm{N}_{2} \mathrm{O}$ gas mixture). K562 cells were plated at an initial density of $0.5 \times 10^{6}$ cells $/ \mathrm{ml}$ and split back to this density every 3 days (with the exception of serum depleted cells which were fed, but not split). Growth (A) and the percentage of dead cells (B) were determined every day. BW5147.3 cells were plated at an initial cell density of $0.4 \times 10^{6} \mathrm{cells} / \mathrm{ml}$ and fed and/or split every 2 days $(C, D)$. Open circles, control cells; closed circles, cells in serum-free medium; closed squares, cells in $B_{12} /$ folatedepleted medium.

each cell line was only marginally affected by depletion of $\mathrm{B}_{12}$ alone (data not shown).

\section{DNA fragmentation in cells incubated in depleted media}

Cells undergoing apoptosis show characteristic high molecular weight and internucleosomal DNA fragmentation patterns (Walker et al, 1995) and the extent of DNA fragmentation seems to be a characteristic of each specific cell type. In this experiment K562 and BW5147.3 cells, grown under conditions described in Figures 1 and 2, were examined for evidence of apoptotic cell death by analysis of DNA isolated at various times after treatment (Figure 3). K562 cells undergo apoptosis following serum withdrawal, but degrade their DNA primarily to high molecular weight fragments only (Walker et al, 1995) as shown in Figure 3A (lanes 2-5). Cells deprived solely of vitamin $B_{12}$ showed no DNA degradation during the first 4 days of culture (lanes $6-9$ ). However, cells depleted of either folate or both vitamin $B_{12}$ and folate showed considerable DNA degradation, typical of apoptosis, by 11 days of culture (Figure 3B). BW5147.3 cells, which degrade their DNA much more extensively to produce internucleosomal DNA fragments, also underwent apoptosis when depleted of either serum or folate and vitamin $\mathrm{B}_{12}$ (Figure $3 \mathrm{C}$ ).

\section{Dissection of folate and vitamin $\mathrm{B}_{12}$ growth requirements}

The data described above suggested that when folic acid is present in the medium the cells have little requirement for vitamin $B_{12}$. To evaluate this BW5147.3 cells were grown in medium deficient in either folate, vitamin $B_{12}$ or both (Figure 4). As in the experiment described in Figure 2, the cells 
depleted of both folate and $\mathrm{B}_{12}$ lost viability after 6 days, whereas cells depleted in folate alone did not begin to lose viability until 2 days later. In this longer-term experiment, cells incubated in medium depleted of vitamin $\mathrm{B}_{12}$ (and exposed to the $\mathrm{N}_{2} \mathrm{O}$ gas mixture) eventually ceased proliferating and began to lose viability, but not until after 10-12 days in culture. Similar results were obtained following prolonged incubations of K562, L1210 and U937 cells (data not shown).

In a further experiment to more directly demonstrate $B_{12^{-}}$ dependent growth, K562 cells were adapted to grow in a serum-free medium so that the levels of folate and vitamin $B_{12}$ which the cells were exposed to could be controlled completely (fetal bovine serum can contribute sufficient $B_{12}$ to support growth as well as substantial amounts of folate). This experiment also allowed us to determine the rate of depletion of intracellular $B_{12}$ by incubating the cells in the presence or absence of $\mathrm{N}_{2} \mathrm{O}$ (Figure 5). Cells incubated in serum-free medium, without folic acid and supplemented with $5 \mu \mathrm{M} \mathrm{MeTHF}$, and also containing vitamin $\mathrm{B}_{12}$ (control cells) completed two cell cycles in the 5 days of the experiment and this was not significantly affected by leaving vitamin $B_{12}$ out of the medium (Figure 5A). Clearly, there is sufficient endogenous $B_{12}$ to support at least two cell cycles. However, when the cells were also exposed to $\mathrm{N}_{2} \mathrm{O}$ at the time of removal of $\mathrm{B}_{12}$ the population only doubled and there was no further net accumulation of cells. Flow cytometric analysis of the cell population showed an accumulation of some cells in early S-phase (data not shown). The culture also began to lose viability almost immediately suggesting that some cells were still in cycle whereas others were undergoing apoptosis. Indeed, when the morphology of these cells was examined by fluorescence microscopy (Figure 5C) apoptotic cells with highly condensed nuclei as well as apoptotic bodies were readily seen.

\section{Effects of nitrous oxide on intracellular methionine synthase activity}

Although $\mathrm{N}_{2} \mathrm{O}$ has been shown to alter MS activity in vitro (Deacon et al, 1980; Kondo et al, 1981; Christensen and Ueland, 1993) the kinetics of its effect on cultured cells has not been examined. To establish the kinetics by which nitrous oxide was able to inactivate vitamin $B_{12}$ resulting in a loss of MS activity the enzyme was assayed in a number of cell lines at various times after the onset of exposure to the gas mixture (Figure 6). Both apo- and holoenzyme activities were determined. Apoenzyme activity indicates the immediate effects of $\mathrm{N}_{2} \mathrm{O}$ on vitamin $\mathrm{B}_{12}$-bound enzyme, i.e. the effects of inactivation of functional activity, whereas holoenzyme
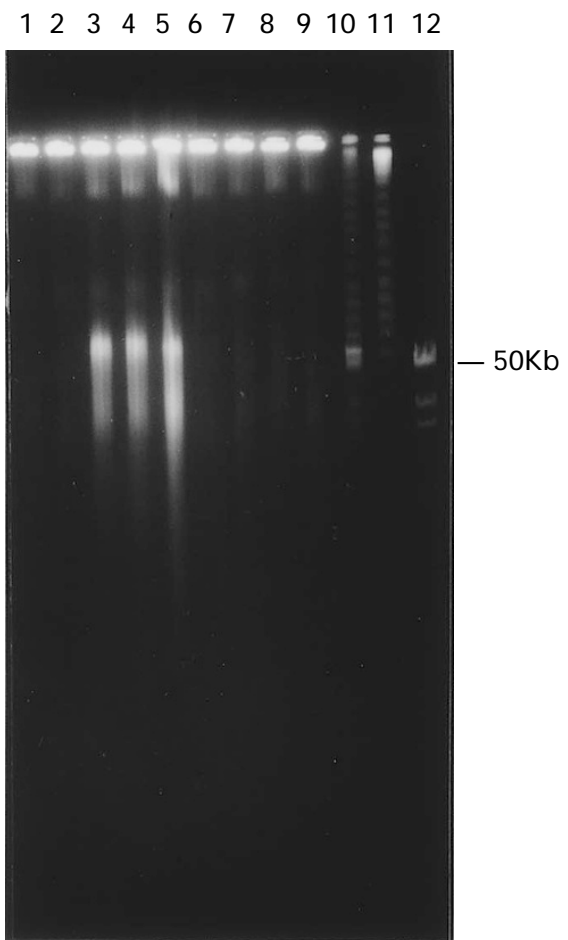

$\begin{array}{lllllll}1 & 2 & 3 & 4 & 5 & 6 & 7\end{array}$

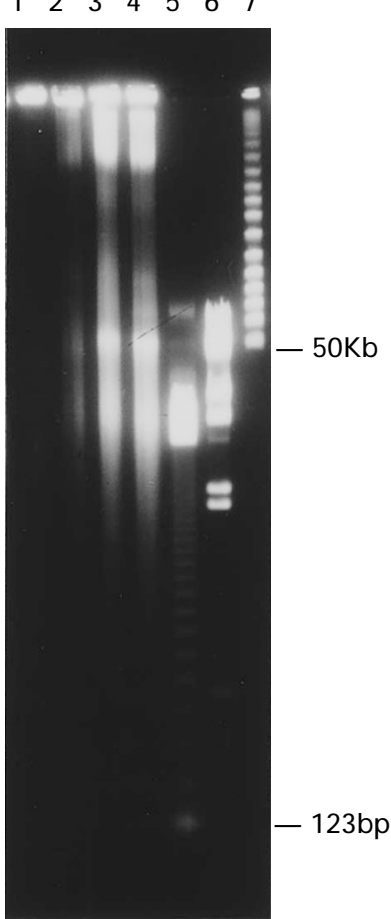

C

$\begin{array}{lllllllllll}1 & 2 & 3 & 4 & 5 & 6 & 7 & 8 & 9 & 10 & 11\end{array}$

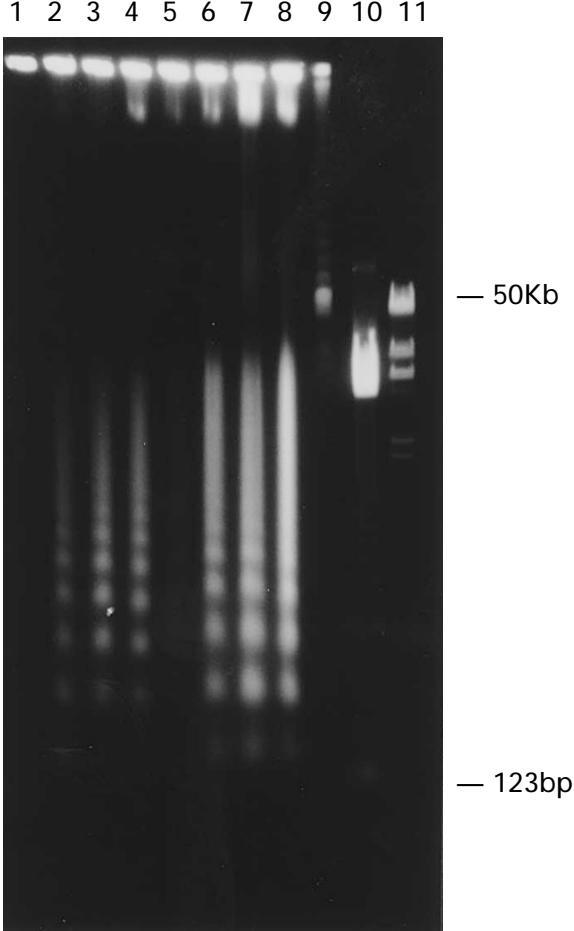

Figure 3 DNA fragmentation in K562 (A,B) and BW5147.3 (C) cells determined by pulsed field gel electrophoresis. In A, lane (1)=DNA from starting cell culture; lanes $2-5$, DNA from cells incubated for $24,48,72$ and $96 \mathrm{~h}$ in serum-free medium; lanes $6-10$, DNA from cells incubated in medium - $\mathrm{B}_{12}\left(+\mathrm{N}_{2} \mathrm{O}\right)$. Lanes $10-12$, molecular size markers; Yeast chromosomes, Lambda ladder (multimers of $48.5 \mathrm{~Kb}$ ) and Hindll//lambda DNA digest, respectively. The sizes of representative markers are shown to the right. In B, lane 1=DNA from starting culture; lanes 2-4, DNA from cells grown for 11 days in complete medium, folate-depleted medium or $\mathrm{B}_{12}$ /folate depleted medium, respectively. Lanes 5-7, molecular size markers; 123 bp ladder, HindlI//ambda DNA digest and Lambda ladder, respectively. In C, DNA from BW5147.3 cells grown for 1, 2, 3 or 4 days in serum-free medium (lanes 1-4) or medium depleted in $B_{12}$ and folate (lanes $5-8$ ). Lanes $9-11$, molecular size markers; Yeast chromosomes, 123 bp ladder and, HindlII/lambda DNA digest, respectively. 
activity reflects the effects of $\mathrm{N}_{2} \mathrm{O}$ on total enzyme protein. In all cases, apoenzyme activity was rapidly lost and became undetectable within 6-12 h. Interestingly, holoenzyme activity also declined throughout the $72 \mathrm{~h}$ exposure to gas, particularly in the case of K562 cells. A similar loss of holoenzyme activity was seen in the liver of rats exposed to

A
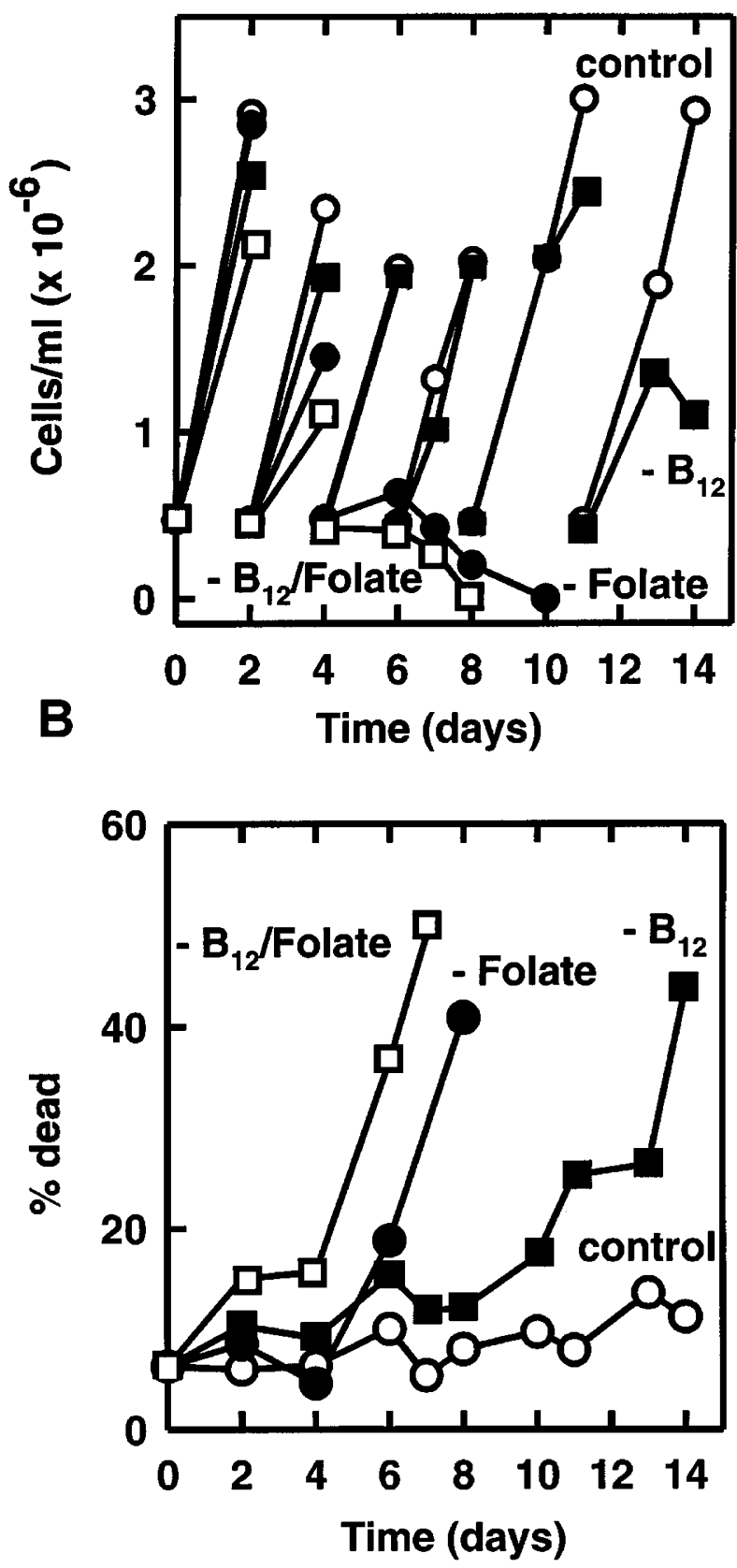

Figure 4 Growth of K562 cells in normal medium or medium depleted in either $B_{12}\left(-B_{12}\right)$ or folate (-Folate) or both $\left(-B_{12} /\right.$ Folate) as indicated. Cells were plated at $0.5 \times 10^{6} \mathrm{cells} / \mathrm{ml}$ and split and fed every 2 days until growth ceased. A, live cell counts $/ \mathrm{ml}$ of medium. B, Percentage of trypan blue positive cells. Open circles, control cells; closed circles, folate-depleted; closed squares, $B_{12}$-depleted medium; open squares, $B_{12}$ Ifolate-depleted medium.
$\mathrm{N}_{2} \mathrm{O}$ for prolonged periods (Kondo et al, 1981). The different cell types had substantially different levels of MS activity and the K562 cells had a much higher MS activity and a much higher fraction $(35 \%)$ of the enzyme was occupied by $B_{12}$ compared with the other cells $(5-10 \%$, Table 1$)$.

\section{Comparison of kinetics of cell death induced by $B_{12}$-depletion and MTX}

The rate of cell death seen in K562 cells following $B_{12} /$ folatedepletion seen in Figure $2 \mathrm{~B}$ was compared with the rate at which MTX killed the cells (Figure 7A). In this experiment cells were exposed to $100 \mathrm{nM} \mathrm{MTX}$ and the percentage of trypan blue positive cells counted each day. A significant increase in cell death was observed 3-4 days after treatment and by day 8 the entire cell population was dead. In contrast, cell death began almost immediately after serum withdrawal, but did not start until $6-7$ days after $B_{12}$ /folate-depletion. However, once started the rate of cell death following depletion was similar to that seen in MTX-treated cells (Figure 7B). In this figure the rate of cell death of $\mathrm{K} 562$ cells is compared for serum withdrawal, MTX treatment and $\mathrm{B}_{12} /$ folate depletion. Regression analysis showed that upon serum withdrawal the culture began to undergo apoptosis almost immediately with $19 \%$ of the cells being lost/day. In the presence of MTX approximately $16 \%$ of the cells died/day after a 2 day delay in onset. Similarly, $16 \%$ of the cells were lost/day in cells depleted of $\mathrm{B}_{12} /$ folate, but there was a delay of 6 days before cell death commenced. Similar results were obtained with the other cell lines (data not shown).

\section{Discussion}

The only documented effect of incubating cells or tissues with $\mathrm{N}_{2} \mathrm{O}$, in the presence of normal oxygen levels $(20 \%)$ is the oxidation of Coll to Colll resulting in an effective depletion of vitamin $B_{12}$. In this manuscript we have shown that depletion of functional vitamin $\mathrm{B}_{12}$ with $\mathrm{N}_{2} \mathrm{O}$ in a variety of transformed cell lines triggers apoptosis. Given that vitamin $\mathrm{B}_{12}$ depletion is specific, at least in the short-term, for proliferating cells it can form the basis of a therapeutic strategy aimed at elimination of cancerous cells by specifically inducing apoptosis. Until now, only a cumbersome, irreproducible method of $\mathrm{B}_{12}$ depletion was available, i.e. $\mathrm{N}_{2} \mathrm{O}$ inhalation. This was the only reason for the abandonment of this therapeutic approach, despite documented efficacy in leukemia patients with minimal toxicity (Lassen and Kristen, 1959; Eastwood et al, 1963; Ikeda et al, 1989). We are developing 'growth blockers' aimed at antagonising the uptake of vitamin $B_{12}$ via the proliferation-associated $B_{12} /$ TCII receptor. We are using two approaches: one called receptor modulation (Pathare et al, 1996) aimed at interfering with the expression and intracellular routing of $B_{12}$ receptors (and thereby delivery of $B_{12}$ to intracellular methionine synthase). The second approach uses monoclonal antibodies to TCII (Quadros et al, 1996; McLean et al, 1996), the $B_{12}$ serum transport protein, to inhibit binding to the cell receptor and thereby producing a depletion of $\mathrm{B}_{12}$.

Nitrous oxide completely inhibits functional MS (apoenzyme) activity in these cultured cells with kinetics similar to 
A

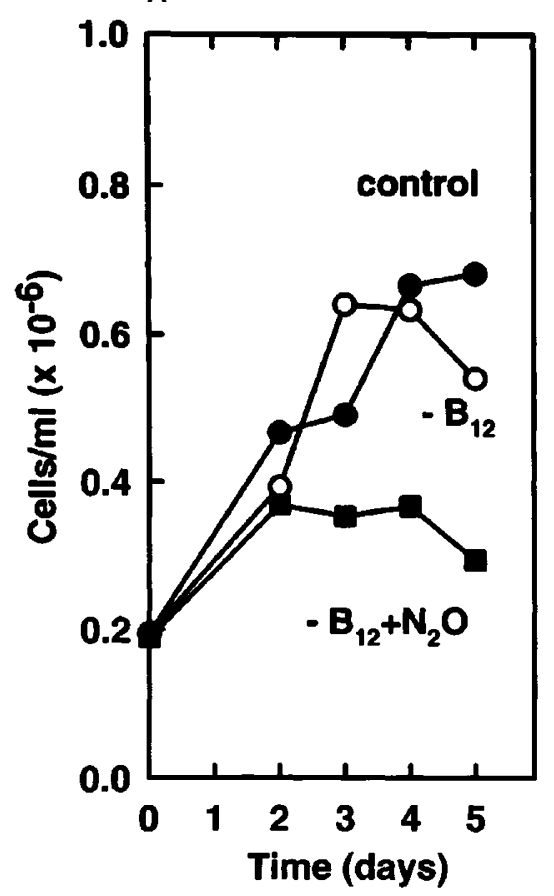

B

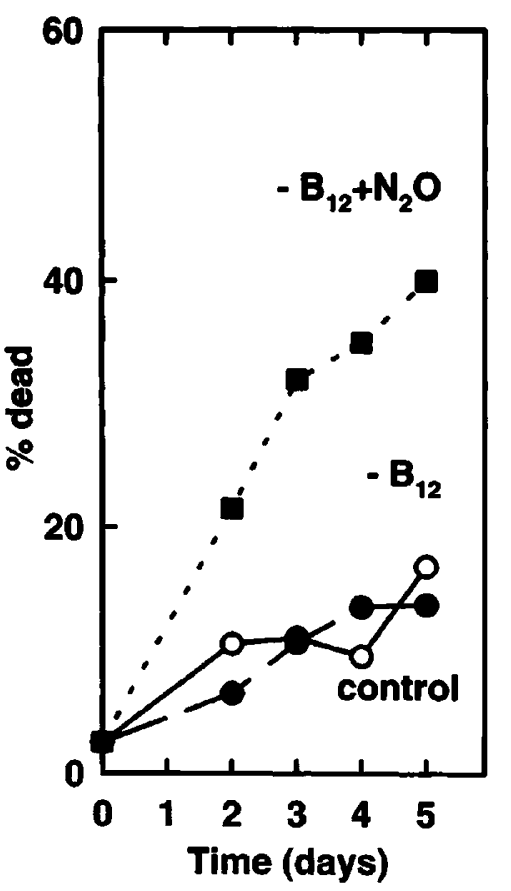

C

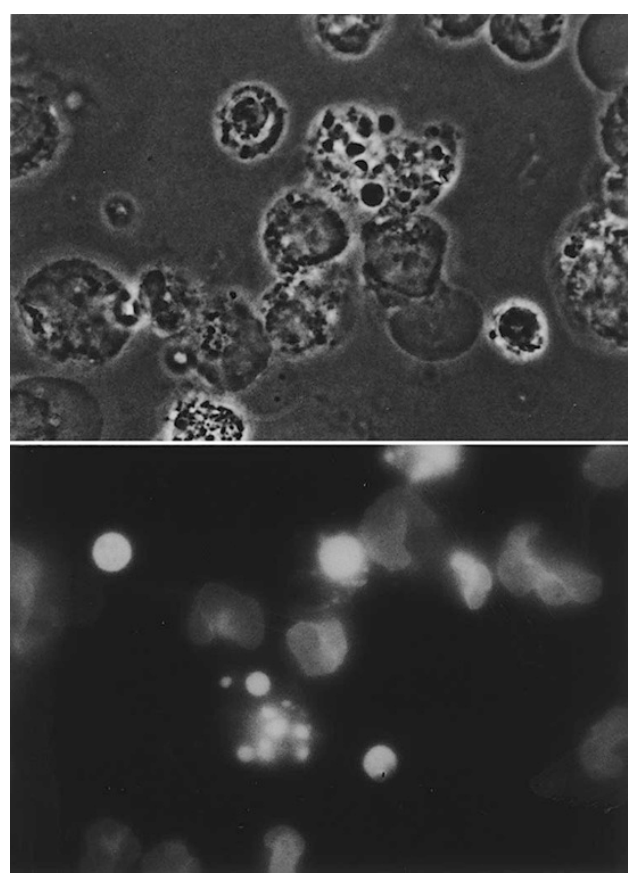

Figure 5 Growth and apoptosis of K562 cells in serum-free medium. Cells were plated at $0.2 \times 10^{6}$ cells/ml in either the serum-free medium (-folate+MeTHF+B 12 , closed circles) described in the Materials and Methods or the same medium without vitamin $\mathrm{B}_{12}$ and incubated in air- $\mathrm{CO}_{2}$ for 5 days (open circles). Parallel cultures were set up in medium without vitamin $\mathrm{B}_{12}$ and incubated in the $\mathrm{N}_{2} \mathrm{O}$ mixture for 5 days (closed squares). Live cell counts (A) and the percentage of trypan blue positive cells (B) were determined each day. C, Phase contrast microscopy (upper panel) and Hoechst staining (lower panel) of cells 5 days after incubation in medium without vitamin $B_{12}$ and incubated in the $\mathrm{N}_{2} \mathrm{O}$ mixture. The data are representative of several such experiments.

those seen in vivo (Kondo et al, 1981; Chanarin et al, 1985). It has been shown that in vivo there is a subsequent loss of folates (Chanarin, 1982) and derangements in deoxyribonucleotide pools (Chanarin et al, 1985; Wickramsinghe and Fida, 1993). Deoxyribonucleotide pool imbalance results in a lowered dTTP pool and misincorporation of nucleotides into DNA during replication (Wickramsinghe and Fida, 1993) eventually triggering cell death (Yoshioka et al, 1987). Since methylmalonylCoA mutase activity is not affected by short-term exposure to $\mathrm{N}_{2} \mathrm{O}$ (Kondo et al, 1981; Chanarin et al, 1985) it is unlikely to contribute to the death of the cell.

Reproducible in vitro effects of vitamin $\mathrm{B}_{12}$ depletion on cell growth and cell death have been difficult to obtain because the composition of most cell culture media do not reflect the cellular environment in vivo. For example, most cells in vivo are not normally exposed to folic acid (Chanarin, 1982). Folates from the diet are converted to MeTHF and transported to peripheral tissues in this form. Thus, cells in vivo are completely dependent upon the MS reaction to convert MeTHF to THF and replenish the folic acid cycle. Cells in culture, on the other hand, are exposed directly to folic acid as the normal supplement of most media. Because cells cannot directly convert folic acid to MeTHF the folate is believed to enter the folate cycle by being successively reduced to dihydro- and then tetrahydrofolic acid. Since in complete RPMI medium the level of folic acid $(2.3 \mu \mathrm{M})$ is orders of magnitude higher than serum folates cells in vitro have little or no requirement for MS enzyme (or vitamin $B_{12}$ ) to maintain adequate folate cycle activity to support DNA replication. The slightly reduced growth rate seen when cells are depleted only of $B_{12}$ probably reflects the accumulation of some folate as MeTHF (the methyl folate trap, Chanarin, 1985) which may eventually block proliferation (Figure 4). When folic acid is removed from the medium the cells undergo apoptosis and this is accelerated by also inactivating cobalamin (Figure 4). However, a full dependency of proliferation on $B_{12}$ availability is only seen under serumfree conditions (in media supplemented with MeTHF) since even $10 \%$ fetal bovine serum can contribute substantial amounts of folates (Figure 5). Thus, our in vitro model was

Table 1 Methionine Synthase activity in cultured cells

\begin{tabular}{lccc}
\hline Cell Type & $\begin{array}{c}-\mathbf{B}_{\mathbf{1 2}} \\
\left(\mathbf{d} \mathbf{p m} \times \mathbf{1 0}^{-\mathbf{2}} \mathbf{1 0}^{\mathbf{6}} \mathbf{\mathbf { + }} \mathbf{\text { cells }}\right)\end{array}$ & \% Holoenzyme \\
\hline L1210 & 109 & 1094 & 10 \\
BW5147 & 162 & 1523 & 11 \\
CEM & 55 & 1018 & 5 \\
HL60 & 70 & 507 & 14 \\
K562 & 2099 & 5930 & 35 \\
\hline
\end{tabular}

Cells were assayed for MS activity $+/-50 \mu \mathrm{M}$ exogenous cynaocobalamin prior to exposure to the $\mathrm{N}_{2} \mathrm{O}$ mixture. \% holoenzyme is the activity observed in the absence of added cyanocobalamin as a fraction of total activity. 


\section{A. K562}

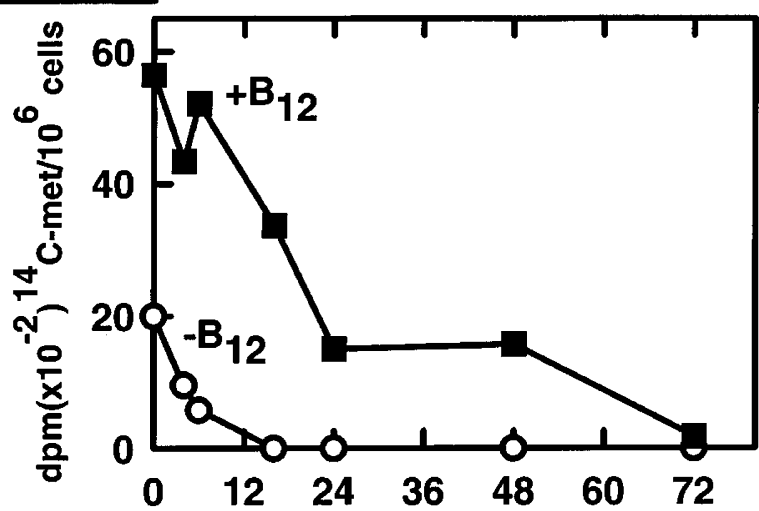

B. BW5147

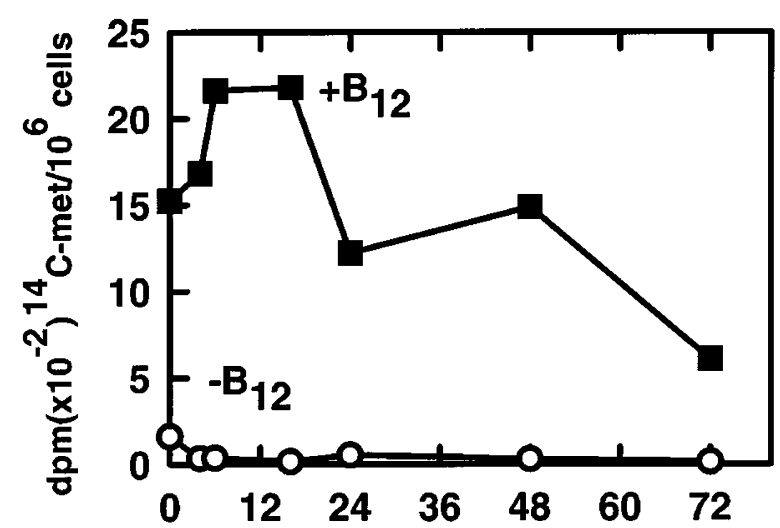

C. $\mathbf{L} 1210$

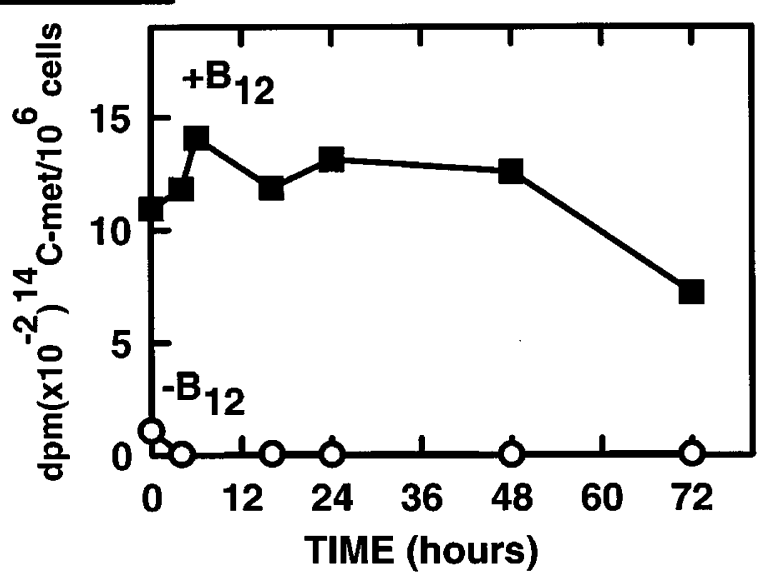

Figure 6 Methionine synthase (MS) activity of (A) K562, (B) BW5147.3 and (C) $\mathrm{L} 1210$ cells during $72 \mathrm{~h}$ of exposure to the $\mathrm{N}_{2} \mathrm{O}$ mixture. Cells were grown in vitamin $B_{12}$-containing media. Cell samples were taken at the times indicated and assayed for activity $+/-50 \mu \mathrm{M}$ exogenous cobalamin (solid squares, open circles, respectively). Activity is expressed as the dpm of $\left[{ }^{14} \mathrm{C}\right]$ methionine produced $/ 10^{6}$ cells.

designed to approach the in vivo conditions in which full dependency on $\mathrm{B}_{12}$ as a co-factor is the rule.

Cells depleted of all growth and survival factors by serum withdrawal, treated with MTX or depleted of $B_{12} /$ folate begin to undergo apoptosis after different lag times. This indicates that a critical threshold or point of commitment to cell death must be achieved and that this point is reached with different kinetics depending on the nature of the inducer. However, once reached the cell population undergoes apoptosis at comparable rates (Figure 7B). All cells must continuously repress apoptosis and serum withdrawal depletes the cells of all the growth and survival factors involved in repression. The cells stop cycling and begin to undergo apoptosis almost immediately. In the case of MTX treatment, the cells also stop cycling almost immediately, but there is a delay of 2 days before the cells respond to the cell cycle block by activating apoptosis. The exact nature of the sensor is unknown. The cells may be sensitive to a prolonged nucleotide pool imbalance, or to the DNA damage that results from misincorporation of nucleotides. Two days are necessary for the threshold to be reached. In the case of $\mathrm{N}_{2} \mathrm{O}$ treatment the cells do not reach this point for 6 days. This, in turn, reflects the additional time required for the cells to be completely depleted of folates which appears to take 3-4 cell cycles. The rate of depletion, and hence the time required to reach the commitment point, is dramatically affected by exogenous folates, even the small amounts present in $10 \%$ serum. In addition, cells grown in the presence of MeTHF can still undergo several cycles unless intracellular levels of $\mathrm{B}_{12}$ are inactivated by $\mathrm{N}_{2} \mathrm{O}$. In the complete absence of medium and serum folates and $B_{12}$ the cells begin to undergo apoptosis within 2 days, similar to the delay seen with MTX. The effects of MTX are not dramatically altered by the presence or absence of exogenous folates since it prevents the folate cycle from operating.

Since the rate of apoptosis, once it commences, is independent of the inducer the most successful strategy, from a therapeutic point of view, is the one that drives cells to the threshold of apoptosis activation with the minimum of cellular damage and the highest degree of selectivity. Since vitamin $B_{12}$ participates in only two cellular reactions, one of which is essential for proliferation, its depletion may represent one of the least disruptive means of blocking growth and inducing apoptosis in cancer cells. Moreover, whereas cells may be able to develop resistance to drugs designed to inhibit or damage specific intracellular targets, it is impossible to overcome the lack of an essential cofactor.

\section{Materials and Methods}

\section{Cell cultures}

The following human and murine cell lines were tested in this study; K562 human chronic myelogenous leukemia, CCRF-CEM human acute lymphoblastic leukemia, U937 human histiocytic lymphoma, BW5147.3 mouse lymphoma and L1210 mouse lymphocytic leukemia. All the cells were maintained in normal or modified RPMI media (Gibco BRL, Burlington, Ontario) containing 10\% (v/v) Fetal Bovine Serum (Unipath, Nepean, ON). Since complete RPMI medium contains 3.7 $\mathrm{nM} \mathrm{B}_{12}$ and 2.3 $\mu \mathrm{M}$ Folic acid, a modified medium without folic acid and vitamin $B_{12}$ was purchased and supplemented with either folic acid or vitamin $B_{12}$ as required for specific experiments. In other experiments, K562 cells were propagated in serum-free RPMI (modified or complete) medium supplemented with $0.1 \%$ bovine 
A

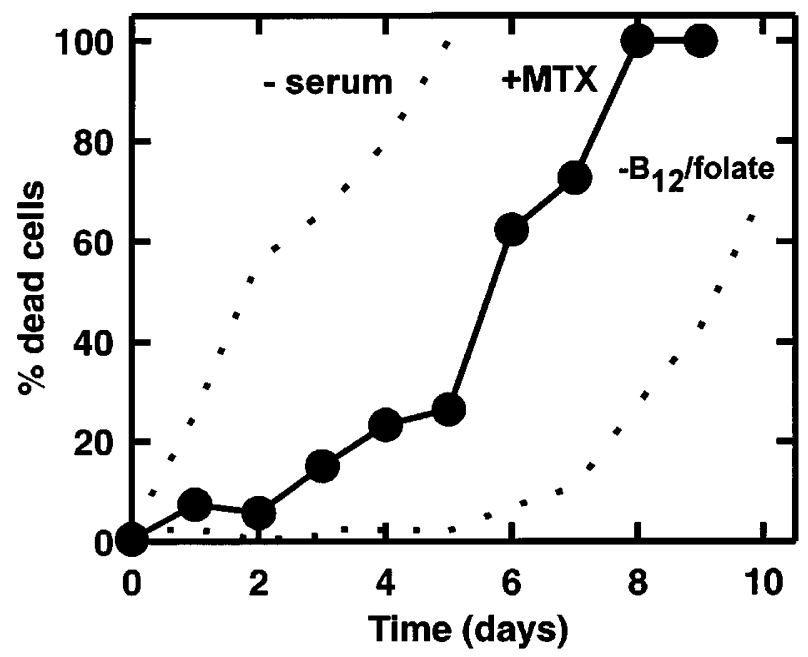

B

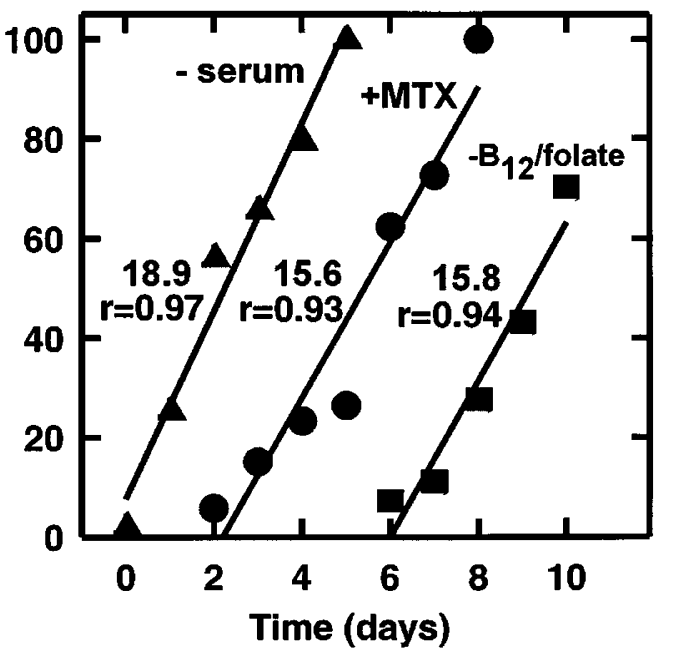

Figure 7 Kinetics of MTX-induced cell death of K562 cells. Cells were treated with $100 \mathrm{nM}$ MTX and the percentage of trypan blue positive cells determined every day $(A)$. Curves for the kinetics of cell death following serum or $B_{12}$ /folate depletion are indicated by dotted lines. $B$, regression analysis of the rates of cell death following the three treatments. The slope as well as the correlation coefficient for each curve are indicated.

serum albumin, $5 \mu \mathrm{g} / \mathrm{ml}$ insulin, $5 \mu \mathrm{g} / \mathrm{ml}$ apotransferrin, $5 \mathrm{ng} / \mathrm{ml}$ selenium and $10 \mathrm{mM}$ hepes buffer, pH 7.2 (Sigma Chemical Co. St Louis, MO).

\section{Nitrous oxide and drug treatments}

Culture media and serum were saturated with a mixture of $50 \% \mathrm{~N}_{2} \mathrm{O}$, $20 \% \mathrm{O}_{2}, 25 \% \mathrm{~N}_{2}$ and $5 \% \mathrm{CO}_{2}$ before being added to cells. Cultures were set up at $0.2-0.5 \times 10^{6} \mathrm{cells} / \mathrm{ml}$ in this media and the flasks of cells were flushed with the same gas mixture, sealed and placed in the incubator. Cells were subsequently fed or split using media saturated as above. Parallel cultures, not exposed to $\mathrm{N}_{2} \mathrm{O}$ were set up in the usual way and placed in the same incubator and exposed to $95 \%$ air, $5 \% \mathrm{CO}_{2}$.

Some cultures were treated with MTX at a dose of $100 \mathrm{nM}$ from a $5 \mathrm{mM}$ stock in dimethylsulphoxide as indicated in the Figure legends.

\section{Analysis of apoptosis}

Cell death by apoptosis was established using morphological and biochemical criteria. For fluorescence microscopy, cells were attached to poly-L-lysine coated coverslips (Sigma, St Louis, MO), fixed for $5 \mathrm{~min}$ in $3 \%$ paraformaldehyde in PBS and rinsed twice briefly with PBS. The coverslips were immersed for $1 \mathrm{~min}$ in $1 \mu \mathrm{g} / \mathrm{ml}$ of Hoechst 33258 in PBS, mounted onto slides and examined using an Olympus Bmax fluorescence microscope as previously described (Weaver et al, 1996). DNA fragmentation, a characteristic of apoptotic cell death, was examined by pulsed field gel electrophoresis (PFGE) as described previously (Walker et al, 1993). Under these electrophoresis conditions both high molecular weight and oligonucleosomal fragments can be resolved on the same gel. Briefly, $2 \times 10^{6}$ cells were immobilized in a low melting point agarose plug and deproteinised for $3 \mathrm{~h}$ at $37^{\circ} \mathrm{C}$ in $300 \mu \mathrm{l}$ of buffer containing $4 \mu \mathrm{g}$ of proteinase $\mathrm{K}, 1 \% \mathrm{SDS}, 10 \mathrm{mM}$ Tris- $\mathrm{HCl}$, pH 9.5, $25 \mathrm{mM}$ EDTA, $1 \mathrm{mM}$ EGTA and $10 \mathrm{mM} \mathrm{NaCl}$. The plugs were rinsed in $10 \mathrm{mM}$ Tris- $\mathrm{HCl}$, $\mathrm{pH} 8.0+1.0 \mathrm{mM}$ EDTA and loaded into the wells of an $0.8 \%$ agarose gel and electrophoresis was carried out using a Q-Life (Kingston, Ontario) Autobase PFGE system. After electrophoresis the gels were stained with ethidium bromide and photographed on a transilluminator using a Polaroid DS-34 camera and positive/negative film no. 55 .

Cell counts were performed using a haemocytometer and cell viability was determined by trypan blue dye exclusion.

\section{Methionine synthase activity}

Methionine synthase activity was assayed essentially as described by Christensen et al (1992). Briefly, $2-5 \times 10^{7}$ cells were harvested, pelleted and lysed in $100 \mu \mathrm{l}$ of $50 \mathrm{mM}$ Potassium phosphate buffer, $\mathrm{pH} 7.4$ containing $100 \mathrm{mM} \mathrm{NaCl}, 10 \mathrm{mM}$ dithiothreitol and $0.05 \%$ Triton X100. Following centrifugation (30 $\mathrm{s}$ in a microfuge), $50 \mu \mathrm{l}$ of extract was assayed in a final reaction volume of $100 \mu \mathrm{l}$ that contained $50 \mathrm{mM}$ potassium phosphate buffer, $\mathrm{pH} 7.4,125 \mathrm{mM} \beta$-mercaptoethanol, $0.4 \mathrm{mM}$ DL-homocysteine, $0.3 \mathrm{mM}$ s-adenosyl methionine, $1 \mu \mathrm{M}$ $(0.2 \mu \mathrm{ci}) \mathrm{N}^{5}$-[methyl $\left.{ }^{14} \mathrm{C}\right]$ methyltetrahydrofolic acid (Amersham, Oakville, ON) $+/-50 \mu \mathrm{M}$ cyanocobalamin. The reaction mixture was overlayed with $50 \mu \mathrm{l}$ of bisphthalate (Fluka, Caledon laboratories, Georgetown, $\mathrm{ON}$ ) and incubations carried out at $37^{\circ} \mathrm{C}$ for $2 \mathrm{~h}$ in the dark. The reaction was stopped by adding $400 \mu \mathrm{l}$ of ice cold water and the radioactive methionine product separated by AG1-X8 (200-400 mesh) column chromatography (Biorad, Mississauga, ON) and counted in a Beckman LS3801 liquid scintillation counter. The data is expressed as $\mathrm{dpm}{ }^{14} \mathrm{C}$-methionine produced $/ 10^{6}$ cells.

\section{References}

Abels J, Kroes ACM, Ermens AAM, van Kapel J, Schoester M, Spijkes LJM and Lindemans J (1990) Anti-leukemic Potential of Methyl-Cobalamin Inactivation by Nitrous Oxide. American Journal of Hematology 34: 128-131

Amagasaki T, Green R and Jacobsen DW (1990) Expression of Transcobalamin II receptors by Human Leukemia K-562 and HL-60 cells. Blood 78: 1380-1386 
Banks RGS, Henderson RJ and Pratt JM (1968) Reactions of Gases in Solution. Part III. Some Reactions of Nitrous Oxide with Transition-metal Complexes. Journa Chemical Society (A): $2886-2889$

Chanarin I (1982) The Effects of Nitrous Oxide on Cobalamins, Folates and on Related Events. CRC Critical Reviews in Toxicology 10: 179-213

Chanarin I, Deacon R, Lumb M, Muir M and Perry J (1985) Coabalamin-Folate Interrelations: A Critical Review. Blood 66: 479-489

Christensen B, Refsum H, Garras A and Ueland PM (1992) Homocysteine Remethylation during Nitrous Oxide Exposure of Cells Cultured in Media Containing Various Concentrations of Folates. Journal of Pharmacology and Experimental Therapeutics 261: 1096-1105

Christensen B and Ueland PM (1993) Methionine Synthase Inactivation by Nitrous Oxide during Methionine Loading of Normal Human Fibroblasts. Homocysteine Remethylation as Determinant of Enzyme Inactivation and Homocysteine Export. Journal of Pharmacology and Experimental Therapeutics 267: 1298 1303

Deacon R, Lumb M, Perry J, Chanarin I, Minty B, Halsey M and Nunn J (1980) Inactivation of Methionine Synthase by Nitrous Oxide. European Journal of Biochemistry 104: 419-422

Eastwood DW, Green CD, Lambdin MA and Gardner R (1963) Effects of Nitrous Oxide on the White Cell Count in Leukemia. New England Journal of Medicine 268: $297-299$

Ermens AAM, Vink N, Schoester M, van Lom K, Lindemans J and Abels J (1989) Nitrous Oxide Selectively Reduces the Proliferation of the Malignant Cells in Experimental Rat Leukemia. Cancer Letters 45: 123-128

Fisher DE (1994) Apoptosis in cancer therapy: Crossing the threshold. Cell 78: 539 542

Hall CA (1984) The Uptake of Vitamin $B_{12}$ by Human Lymphocytes and the Relationships to the Cell Cycle. Journal of Laboratory and Clinical Medicine 103: $70-81$

Hickman JA, Potten CS, Merritt AJ and Fisher TC (1994) Apoptosis and cancer chemotherapy. Philos. Trans. R. Soc. Lond. [Biol] 345: 319-325

Ikeda K, Aosaki T, Furukawa Y, Ohta M, Kano Y, Tsuboyama A, Sakamoto S, Muira Y, Sakuraya K, Fuke N and Kubota T (1989) Antileukmic effect of Nitrous Oxide in a Patient with Chronic Myelogenous Leukemia. American Journal of Hematology 30: 114

James SJ, Basnakian AG and Miller BJ (1994) in vitro folate deficiency induces deoxynucleotide pool imbalance, apoptosis and mutagenesis in chinese hamster ovary cells. Cancer Research 54: 5075-5080

Kerr JFR, Winterford CM and Harmon BV (1994) Apoptosis - Its Significance in Cancer and Cancer Therapy. Cancer 73: 2013-2026

Kondo H, Osborne ML, Kolhouse JF, Binder MJ, Podell ER, Utley CS, Abrams RS and Allen RH (1981) Nitrous Oxide has Multiple Deleterious Effects on Cobalamin Metabolism and Causes Decreases in Activities of Both Mammalian Cobalamindependent Enzymes in Rats. Journal of Clinical Investigation 67: 1270-1283
Kondo H, Iseka T, Iwasa S, Okuda K, Kanazawa S and Ohto M (1989) Cobalamindependent Replication of L1210 Leukemia Cells and Effects of Cobalamin Analogues. Acta Haematologia 81: 61-69

Koury MJ and Horne DW (1994) Apoptosis mediates and thymidine prevents erythroblast destruction in folate deficiency anemia. Proceedings of the National Academy of Sciences of the United 91: 4067-4071

Lassen HCA and Kristensen HS (1959) Remission in Chronic Myeloid Leukemia Following Prolonged Nitrous Oxide Inhalation. Danish Medical Bulletin 6: 252 254

Lindemans J, Kroes AC, van Geel J, van Kapel J, Schoester M and Abels J (1989) Uptake of Transcobalamin II-bound Cobalamin by HL-60 cells: Effects of Differentiation Induction. Experimental Cell Research 184: 449-460

McLean GR, Quadros EV, Rothenberg SP, Morgan AC, Schrader JW and Ziltener HJ (1996) Antibodies to transcobalamin II block in vitro proliferation of leukemic cells. Blood In Press

Parbrook GD (1967) Experimental Studies into the Effects of Nitrous Oxide on Tumour Cell Growth. British Journal of Anaesthesiology 39: 549-553

Pathare PM, Wilbur DS, Heusser S, Quadros EV, McLoughlin P and Morgan AC (1996) Synthesis of cobalamin-biotin conjugates that vary in the position of cobalamin coupling. Evaluation of cobalamin derivative binding to transcobalamin II. Bioconjugate Chem 7:217-232

Quadros EV, Rothenberg SP and McLoughlin PM (1996) Characterisation of monoclonal antibodies to epitopes of Transcobalamin II. Biochem. Biophys. Res. Commun. 222: 149-154

WalkerPR, Kokileva L, Leblanc J and Sikorska M(1993) Detection of the initial stages of DNA fragmentation in apoptosis. Biotechniques 15: 1032-1041

Walker PR, Pandey S and Sikorska M (1995) Degradation of Chromatin in Apoptosis. Cell Death Differ. 2: 97-104

Walker PR, Smith C, Youdale T, Leblanc J, Whitfield JF and Sikorska M (1991) Topoisomerase II-reactive chemotherapeutic drugs induce apoptosis in thymocytes. Cancer Res. 51: 1078-1085

Weaver VM, Carson CE, Walker PR, Chaly N, Lach B, Raymond Y, Brown DL and Sikorska M (1996) Degradation of Nuclear Matrix and DNA Cleavage in Apoptotic Thymocytes. J. Cell Sci. 109: 45-56

Wickramasinghe SN and Fida S (1993) Misincorporation of uracil into the DNA of folate- and $B_{12}$-deficient HL60 cells. Eur. J. Hematol. 50: 127-132

Yoshioka A, Tanaka S, Hiraoka O, Koyama Y, Hirota Y and Wataya Y (1987) Deoxyribonucleosie-triphosphate inbalance death: deoxyadenosine-induced dNTp imbalance and DNA double strand breaks in mouse FM3A cells and the mechanism of cell death. Biochem. Biophys. Res. Commun. 146: 258-264 